\title{
Asas Dan Kriteria Kriminalisasi
}

\author{
Salman Luthan \\ Fakultas Hukum Universitas Islam Indonesia Yogyakarta \\ salman@fh.uii.ac.id
}

\begin{abstract}
In the criminalization, there are three primary principles need to be considered; legality, subsidiary, and equality before the law. The are also criteria to be taken into account; the act shall be in contravention with the sense of justice of the people, the ability of the existing legal framework to cater such act, the balance between the instruments required and the outcomes, the balance between the cost and benefit of the criminalization, the effect of such criminalization, and the last is the ability of the judicial system to enforce the law on the criminalized act.
\end{abstract}

Keywords: Basic principle, Criminalization, Criminal Law

\section{Pendahuluan}

Kriminalisasi (criminalization) merupakan objek studi hukum pidana materiil (substantive criminal law) yang membahas penentuan suatu perbuatan sebagai tindak pidana (perbuatan pidana atau kejahatan) yang diancam dengan sanksi pidana tertentu. Perbuatan tercela yang sebelumnya tidak dikualifikasikan sebagai perbuatan terlarang dijustifikasi sebagai tindak pidana yang diancam dengan sanksi pidana.

Menurut Soerjono Soekanto, kriminalisasi merupakan tindakan atau penetapan penguasa mengenai perbuatan-perbuatan tertentu yang oleh masyarakat atau golongan-golongan masyarakat dianggap sebagai perbuatan yang dapat dipidana menjadi perbuatan pidana ${ }^{1}$ atau membuat suatu perbuatan menjadi perbuatan kriminal dan karena itu dapat dipidana oleh pemerintah dengan cara kerja atas namanya. ${ }^{2}$

${ }^{1}$ Soerjono Soekanto, Kriminologi: Suatu Pengantar, Cetakan Pertama, Jakarta: Ghalia Indonesia, 1981, hlm. 62.

${ }^{2}$ Henry Campbell Black, Black Law Dictionary, Fifth Edition, Sint Paul Minn: West Publishing Co., 1979, hlm. 337. 
Soetandyo Wignjosoebroto mengemukakan bahwa kriminalisasi ialah suatu pernyataan bahwa perbuatan tertentu harus dinilai sebagai perbuatan pidana yang merupakan hasil dari suatu penimbanganpenimbangan normatif (judgments) yang wujud akhirnya adalah suatu keputusan (decisions). ${ }^{3}$ Kriminalisasi dapat pula diartikan sebagai proses penetapan suatu perbuatan seseorang sebagai perbuatan yang dapat dipidana. Proses ini diakhiri dengan terbentuknya undang-undang di mana perbuatan itu diancam dengan suatu sanksi yang berupa pidana. ${ }^{4}$

Di samping itu, pengertian kriminalisasi dapat pula dilihat dari perspektif nilai. Dalam hal ini yang dimaksudkan dengan kriminalisasi adalah perubahan nilai yang menyebabkan sejumlah perbuatan yang sebelumnya merupakan perbuatan yang tidak tercela dan tidak dituntut pidana, berubah menjadi perbuatan yang dipandang tercela dan perlu dipidana. ${ }^{5}$ Dalam perspektif labeling, kriminalisasi adalah keputusan badan pembentuk undang-undang pidana memberi label terhadap tingkah laku manusia sebagai kejahatan atau tindak pidana. ${ }^{6}$

Pengertian kriminalisasi tersebut di atas menjelaskan bahwa ruang lingkup kriminalisasi terbatas pada penetapan suatu perbuatan sebagai tindak pidana yang diancam dengan sanksi pidana. Namun menurut Paul Cornill, pengertian kriminalisasi tidak terbatas pada penetapan suatu perbuatan sebagai tindak pidana dan dapat dipidana, tetapi juga termasuk penambahan (peningkatan) sanksi pidana terhadap tindak pidana yang sudah ada. ${ }^{7}$

\section{Kompleksitas Kriminalisasi}

Kriminalisasi merupakan masalah yang kompleks dan terpisah-pisah ${ }^{8}$ Kompleksitas kriminalisasi terletak pada begitu banyak faktor yang terkait

\footnotetext{
${ }^{3}$ Soetandyo Wignjosoebroto, "Kriminalisasi Dan Dekriminalisasi: Apa Yang Dibicarakan Sosiologi Hukum Tentang Hal Ini, disampaikan dalam Seminar Kriminalisasi Dan Dekriminalisasi Dalam Pebaruan Hukum Pidana Indonesia, Fakultas Hukum UII, Yogyakarta, 15 Juli 1993, hlm. 1.

${ }^{4}$ Sudarto, Kapita Selekta Hukum Pidana, Bandung: Alumni, 1986, hlm. 31.

${ }^{5}$ Rusli Effendi dkk, "Masalah Kriminalisasi dan Dekriminalisasi dalam Rangka Pembaruan Hukum Nasional" dalam BPHN, Simposium Pembaruan Hukum Pidana Nasional Indonesia, Jakarta, Binacipta. 1986, hlm. 64-65.

${ }^{6}$ Hugh D. Barlow, Introduction to Criminology, Third Edition, Boston: Little Brown and Company, 1984, hlm. 9.

${ }^{7}$ Paul Cornill, "Criminality and Deviance in a Changing Whorld", Ceramah pada Kongres PBB IV 1970 mengenai Prevention of Crime and treatment of Offender.
} 
dan perlu dipertimbangkan dalam proses kriminalisasi, dan di antara faktor-faktor tersebut adakalanya terdapat perbedaan yang sangat tajam. Kompleksitas itu berkaitan dengan jenis perbuatan yang dapat dikriminalisasi, dimana jenis perbutan yang dapat dikriminalisasi tersebut bukan hanya meliputi perbuatan yang secara esensial mengandung sifat jahat, tapi juga mencakup perbuatan neteral yang secara hakiki tidak mengandung unsur jahat.

Kompleksitas kriminalisasi juga berhubungan dengan perbedaan nilai dan norma yang dianut oleh kelompok-kelompok masyarakat, baik karena pengaruh latar belakang agama dan budaya, maupun karena pengaruh latar belakang pendidikan dan kelas sosial dalam masyarakat. Perbedaan nilai dan norma mempengaruhi penilaian terhadap perbuatan apa yang patut dikriminalisasi dan berpegaruh juga terhadap penilaian atas gradasi keseriusan perbuatan yang akan dikriminalisasikan.

Kompleksitas kriminalisasi juga tampak dalam beragamnya pilihan instrumen pengaturan kehidupan masyarakat di mana hukum pidana hanya salah satu instrumen pengaturan kehidupan sosial yang tersedia. Instrumen pengaturan kehidupan sosial lainnya adalah hukum perdata, hukum administrasi, moral, agama, disiplin, dan kebiasaan. Hukum pidana tidak boleh ditempatkan sebagai instrumen pertama (primum remedium) untuk mengatur kehidupan masyarakat, melainkan sebagai instrumen terakhir (ultimum remedium) untuk mengontrol tingkah laku individu dalam kehidupan bersama. Oleh karena itu, penggunaan hukum pidana untuk mengatur masyarakat mengenai aktivitas tertentu bukan suatu keharusan, ${ }^{9}$ melainkan hanya salah satu alternatif dari instrumeninstrumen pengaturan yang tersedia.

Kompleksitas kriminalisasi berkaitan juga dengan perubahan sosial dalam masyarakat yang berlangsung secara cepat. Perubahan sosial merupakan salah satu faktor yang mempengaruhi perubahan hukum. Bila masyarakat berubah, maka hukum akan ikut berubah pula. Perubahan

${ }^{8}$ A.P. Simester dan G R Sullivan, Criminal Law Theory and Doctrine, Oxford: Hart Publishing, 2000, hlm. 6.

${ }^{9}$ Hukum pidana harus digunakan secara hemat karena sanksi pidana merupakan sanksi hukum yang paling keras dan dapat menimbulkan stigma bagi orang yang dijatuhi sanksi tersebut. Penggunaan hukum pidana untuk mengatur aktivitas masyarakat menunjukkan kecenderungan berlebihan di negara-negara totaliter dan relatif hemat di negara-negara demokratis. Hukum pidana harus digunakan secara hemat bila tertib sosial berjalan secara baik, dan dapat digunakan secara berlebihan bila kondisi sosial tidak tertib. 
hukum merupakan resultante dari perubahan masyarakat. ${ }^{10}$ Pola hubungan masyarakat dan hukum seperti ini tergambar dalam ungkapan adat sakali aie gadang sakali titian baranjak. ${ }^{11}$

Perubahan sosial yang terjadi dalam masyarakat meliputi perubahan besar dalam susunan masyarakat yang mempengaruhi sendi-sendi kehidupan bersama dan perubahan nilai-nilai budaya yang mempengaruhi alam pikiran, mentalitas serta jiwa. ${ }^{12}$ Dengan kata lain, perubahan sosial tidak hanya berarti perubahan struktur dan fungsi masyarakat, tetapi di dalamnya terkandung juga perubahan nilai, sikap dan pola tingkah laku masyarakat. ${ }^{13}$

Perubahan nilai pada dasarnya adalah perubahan pedoman kelakuan dalam kehidupan masyarakat. Jenis perubahan nilai dapat dibedakan dalam dua hal, yaitu: (1) perubahan nilai-nilai budaya primordial yang ditentukan oleh kelompok kekerabatan, komunikasi desa, ke suatu sistem budaya nasional ....... , dan (2) perubahan sistem nilai tradisional kepada sistem nilai budaya modern. ${ }^{14}$

Akibat perubahan sosial tersebut, perbuatan-perbuatan tertentu yang dulu dikualifikasikan sebagai perbuatan tercela atau merugikan masyarakat, kini dianggap sebagai perbuatan yang wajar dan tidak tercela. Di Indonesia misalnya, tindakan mempertunjukkan alat-alat KB di muka umum, gelandangan dan perang tanding masih diatur dalam KUHP. ${ }^{15}$

${ }^{10}$ Pola hubungan hukum dan perubahan sosial bukan hanya dalam bentuk perubahan sosial mempengaruhi perubahan hukum, tapi juga perubahan hukum dapat mempengaruhi perubahan soasial. Undang-undang yang mengalami perubahan secara cepat adalah undang-undang khusus di bidang ekonomi, sedangkan undang-undang terkodifikasi sangat sulit berubah karena mengatur banyak hal, tersusun secara sistematis dan terstruktur secara sistemik.

${ }^{11}$ Ungkapan tersebut berasal dari pribahasa Minang yang berarti “bila air sungai pasang dan meluap, maka jembatan (titian) akan bergeser dari tempatnya.

${ }^{12}$ Koentjaraningrat, "Pergeseran Nilai-Nilai Budaya dalam Masa Transisi" dalam BPHN, Kesadaran Hukum Masyarakat dalam Masa Transisi, Jakarta: Binacipta, tanpa tahun, hlm. 25.

${ }^{13}$ Rusli Effendi dkk, mengutip Selo Soemardjan dalam "Masalah Kriminalisasi dan Dekriminalisasi dalam Rangka Pembaruan Hukum Nasional" dalam BPHN, Simposium Pembaruan Hukum Pidana Nasional Indonesia, Jakarta, Binacipta. 1986, hlm. 64-65.

${ }^{14}$ Koentjaraningrat, Op. Cit, hlm. 26.

15/Kriminalisasi perbuatan mempertunjukkan alat-alat KB di muka umum dilatarbelakangi oleh tingkat pertumbuhan penduduk yang sangat pesat dan tingkat produksi barang-barang konsumsi yang relatif lamban, dan untuk mencegah penyalahgunaan alat-alat KB untuk kepentingan seks bebas. Kriminalisasi tindakan pergelandangan didorong oleh sifat orang yang malas bekerja dan kebutuhan tenaga kerja yang meningkat tajam pada masa revolusi industri. 
Sebaliknya ada pula perbuatan-perbuatan tertentu yang dulu dikualifikasikan sebagai perbuatan yang wajar, kini berubah sifatnya menjadi perbuatan jahat, tercela dan merugikan masyarakat. Misalnya, pencemaran lingkungan, praktek monopoli dalam ekonomi ${ }^{16}$, pencucian uang, dan merugikan konsumen.

\section{Asas-asas Kriminalisasi}

Asas adalah prinsip-prinsip atau dasar-dasar atau landasan pembuatan suatu peraturan, kebijakan dan keputusan mengenai aktivitas hidup manusia. Asas hukum merupakan norma etis, konsepsi falsafah negara, dan doktrin politik. ${ }^{17}$ Di samping itu, asas hukum juga merupakan pikiranpikiran yang menuntun, pilihan terhadap kebijakan, prinsip hukum, pandangan manusia dan masyarakat, kerangka harapan masyarakat. ${ }^{18}$

Menurut Scholten, asas-asas hukum adalah pikiran-pikiran yang tidak ditegaskan secara eksplisit dalam undang-undang. Ukuran kepatutan menurut hukum dapat dicari dalam pikiran-pikiran yang ada di belakang naskah undang-undang. Sedangkan menurut Van Hoecke, asas-asas hukum adalah opsi-opsi dasar bagi kebijakan kemasyarakatan yang aktual, dan prinsip-prinsip etik hukum. ${ }^{19}$

Dalam konteks kriminalisasi, asas diartikan sebagai konsepsi-konsepsi dasar, norma-norma etis, dan prinsip-prinsip hukum yang menuntun pembentukan norma-norma hukum pidana melalui pembuatan peraturan perundang-undangan pidana. Dengan kata lain, asas hukum adalah konsepsi dasar, norma etis, dan prinsip-prinsip dasar penggunaan hukum pidana sebagai sarana penanggulangan kejahatan.

Ada tiga asas kriminalisasi yang perlu diperhatikan pembentuk undang-undang dalam menetapkan suatu perbuatan sebagai tindak

${ }^{16}$ Kriminalisasi perbuatan pencemaran lingkungan didorong oleh tingkat pemcemaran lingkungan dalam skala besar yang dilakukan industri-industri besar yang akibatnya sangat berbahaya bagi keselamatan manusia dan kelestarian lingkungan. Kriminalisasi praktek monopoli dipicu oleh persaingan curang dalam praktek bisnis.

${ }^{17}$ Roeslan Saleh, "Kebijakan Kriminalisasi Dan Dekriminalisasi: Apa Yang Dibicarakan Sosiologi Hukum Dalam Pembaruan Hukum Pidana Indonesia", disampaikan dalam Seminar Kriminalisasi dan Dekriminalisasi dalam Pebaruan Hukum Pidana Indonesia, Fakultas Hukum UII, Yogyakarta, 15 Juli 1993, hlm. 38-39.

${ }^{18}$ Ibid., hlm. 29.

${ }^{19} \mathrm{Ibid} ., \mathrm{hlm} .27-28$. 
pidana beserta ancaman sanksi pidananya, yakni: (1) asas legalitas; (2) asas subsidiaritas, dan (3) asas persamaan/kesamaan. Pertama, asas legalitas yaitu, asas yang esensinya terdapat dalam ungkapan nullum delictu, nulla poena sie praevia lege poenali yang dikemukakan oleh von Feurbach. Ungkapan itu mengandung pengertian bahwa "tidak ada suatu perbuatan yang dapat dipidana kecuali atas perundang-undangan pidana yang sudah ada sebelum perbuatan itu dilakukan". Asas legalitas adalah asas yang paling penting dalam hukum pidana, khususnya asas pokok dalam penetapan kriminalisasi.

Menurut Schafmeister dan J.E. Sahetapy ${ }^{20}$ asas legalitas mengandung tujuh makna, yaitu: (i) tidak dapat dipidana kecuali berdasarkan ketentuan pidana menurut undang-undang; (ii) tidak ada penerapan undang-undang pidana berdasarkan analogi; (iii) tidak dapat dipidana hanya berdasarkan kebiasaan; (iv) tidak boleh ada perumusan delik yang kurang jelas (syarat lex certa); (v) tidak ada kekuatan surut dari ketentuan pidana; (vi) tidak ada pidana lain kecuali yang ditentukan undang-undang; dan (vii) penuntutan pidana hanya menurut cara yang ditentukan undang-undang.

Dalam doktrin hukum pidana ada enam macam fungsi asas legalitas. Pertama, pada hakikatnya, asas legalitas dirancang untuk memberi maklumat kepada publik seluas mungkin tentang apa yang dilarang oleh hukum pidana sehingga mereka dapat menyesuaikan tingkah lakunya. ${ }^{21}$

Kedua, menurut aliran klasik, asas legalitas mempunyai fungsi untuk membatasi ruang lingkup hukum pidana. Sedangkan dalam aliran modern asas legalitas merupakan instrumen untuk mencapai tujuan perlindungan masyarakat. $^{22}$

Ketiga, fungsi asas legalitas adalah untuk mengamankan posisi hukum rakyat terhadap negara (penguasa). Hal ini adalah tafsiran tradisional yang telah mengenyampingkan arti asas legalitas sepenuhnya seperti dimaksudkan oleh ahli-ahli hukum pidana pada abad ke XVIII (delapanbelas). ${ }^{23}$

${ }^{20}$ J.E. Sahetapy (Ed.), Hukum Pidana, Yogyakarta: Penerbit Liberty, 1996, hlm. 6-7.

${ }^{21}$ Abdullah Ahmed An-Naim, Dekonstruksi Syari'ah, Yogyakarta, LkiS dan Pustaka Pelajar, 1990, hlm. 197.

${ }^{22}$ Antonie A.G. Peters, "Main Current in Criminal Law Theorie", in Criminal Law in Action, Gouda Quint by, Arnhem, 1986, hal. 33, dikutip dari Kamariah, "Ajaran Sifat Melawan Hukum Material Dalam Hukum Pidana Indonesia", Pidato Pengukuhan Guru Besar, UNPAD, Bandung, Maret 1994, hlm 43.

${ }^{23}$ Roeslan Saleh mengutip Antonie A.G. Peter, dalan Asas Hukum Pidana Dalam Perspektif, Jakarta: Aksara Baru, 1981, hlm. 28. 
Keempat, asas legalitas dikaitkan dengan peradilan pidana, mengharapkan lebih banyak lagi daripada hanya akan melindungi warga masyarakat dari kesewenang-wenangan pemerintah. Asas legalitas itu diharapkan memainkan peranan yang lebih positif, yaitu harus menentukan tingkatan-tingkatan dari persoalan yang ditangani oleh suatu sistem hukum pidana yang sudah tidak dapat dipakai lagi. ${ }^{24}$

Kelima, tujuan utama asas legalitas adalah untuk membatasi kesewenang-wenangan yang mungkin timbul dalam hukum pidana dan mengawasi serta membatasi pelaksanaan dari kekuasaan itu atau menormakan fungsi pengawasan dari hukum pidana itu. Fungsi pengawasan ini juga merupakan fungsi asas kesamaan, asas subsidiaritas, asas proporsionalitas, dan asas publisitas. ${ }^{25}$

Keenam, asas legalitas memberikan kepastian hukum kepada masyarakat mengenai perbuatan-perbuatan yang dilarang (tindak pidana) yang disertai dengan ancaman pidana tertentu. Dengan adanya penetapan perbuatan terlarang itu berarti ada kepastian (pedoman) dalam bertingkah laku bagi masyarakat.

Dari enam fungsi asas legalitas tersebut, fungsi asas legalitas yang paling relevan dalam konteks kriminalisasi adalah fungsi kedua yang berkenaan dengan fungsi untuk membatasi ruang lingkup hukum pidana, dan fungsi ketiga yang berkaitan dengan fungsi mengamankan posisi hukum rakyat terhadap negara. Fungsi asas legalitas untuk mengamankan posisi hukum rakyat terhadap negara dan fungsi untuk melindungi anggota masyarakat dari tindakan sewenang-wenang pihak pemerintah merupakan dimensi politik hukum dari asas legalitas. ${ }^{26}$

Keberadaan hukum pidana harus dibatasi karena hukum pidana merupakan bidang hukum yang paling keras dengan sanksi yang sangat berat, termasuk sanksi pidana mati. Hukum pidana digunakan hanya untuk melindungi kepentingan masyarakat yang sangat vital bagi kehidupan bersama. Perbuatan-perbuatan yang perlu dikriminalisasi adalah perbuatan-perbuatan yang secara langsung mengganggu ketertiban kehidupan masyarakat. .

Fungsi mengamankan posisi hukum rakyat terhadap negara juga harus menjadi fokus perhatian hukum pidana. Hukum pidana harus dapat menjamin hak-hak dasar setiap warganegara, dan pembatasan terhadap

\footnotetext{
${ }^{24}$ Ibid, hlm. 35.

${ }^{25}$ Ibid., hlm. 14.

${ }^{26}$ Ibid., hlm. 28.
} 
hak-hak dasar warga negara melalui instrumen hukum pidana sematamata dimaksudkan untuk menjamin hak-hak dasar bagi semua warga negara. Fungsi asas legalitas untuk mengamankan posisi hukum rakyat terhadap negara dan fungsi untuk melindungi anggota masyarakat dari tindakan sewenang-wenang pihak pemerintah merupakan dimensi politik hukum dari asas legalitas. ${ }^{27}$

Dalam praktek perundang-undangan asas legalitas ternyata tidak dapat memainkan peranan untuk melindungi posisi hukum rakyat terhadap penguasa dan untuk membatasi kesewenang-wenangan pemerintah di dalam membuat hukum dan proses penegakan hukum. Asas legalitas hanya berfungsi sebagai dasar hukum bagi pemerintah untuk bertindak mengatur kehidupan masyarakat melalui penetapan tindak pidana yang tidak jarang merugikan kepentingan masyarakat, terutama pada masa Orde Baru. Dengan bertambahnya tindak pidana, bukan hanya merusak dimensi kegunaan dari asas legalitas menjadi rusak, tetapi juga asas perlindungan hukum. ${ }^{28}$

Kedua, di samping berlandaskan kepada asas legalitas, kebijakan kriminalisasi juga harus berdasarkan kepada asas subsidiaritas. Artinya, hukum pidana harus ditempatkan sebagai ultimum remedium (senjata pamungkas) dalam penanggulangan kejahatan yang menggunakan instrumen penal, bukan sebagai primum remedium (senjata utama) untuk mengatasi masalah kriminalitas.

Penerapan asas subsidiaritas dalam kebijakan kriminalisasi dan dekriminalisasi mengharuskan adanya penyelidikan tentang efektivitas penggunaan hukum pidana dalam penanggulangan kejahatan atau perbuatan-perbuatan yang merugikan masyarakat. Pokok permasalahan yang perlu diteliti adalah apakah tujuan-tujuan yang ingin dicapai dengan menggunakan hukum pidana itu tidak dapat dicapai juga dengan menggunakan cara-cara lain yang lebih kecil ongkos sosial dan individualnya? Hal ini menghendaki agar kita mengetahui tentang akibatakibat dari penggunaan hukum pidana itu, dan dapat menjamin bahwa campur tangan hukum pidana itu memang sangat berguna. ${ }^{29}$

Apabila dalam penyelidikan itu ditemukan bahwa penggunaan sarana-sarana lain (saranan non penal) lebih efektif dan lebih bermanfaat untuk menanggulangi kejahatan, maka janganlah menggunakan hukum pidana. Dalam praktek perundang-undangan, upaya untuk mengadakan

\footnotetext{
${ }^{27}$ Ibid., hlm. 28.

${ }^{28}$ Ibid., hlm. 61-62.

${ }^{29}$ Roeslan Saleh, Op.Cit, hlm. 61.
} 
penyelidikan tersebut bukan hanya tidak dilakukan, tapi juga tidak terpikirkan. Penggunaan asas subsidiaritas dalam praktek perundangundangan ternyata tidak berjalan seperti diharapkan. Hukum pidana tidak merupakan ultimum remedium melainkan sebagai primum remedium. Penentuan pidana telah menimbulkan beban terlalu berat dan sangat berlebihan terhadap para justitiable dan lembaga-lembaga hukum pidana. ${ }^{30}$

Kenyataan yang terjadi dalam praktek perundang-undangan adalah adanya keyakinan kuat di kalangan pembentuk undang-undang bahwa penetapan suatu perbuatan sebagai perbuatan terlarang yang disertai dengan ancaman pidana berat mempunyai pengaruh otomatis terhadap perilaku anggota masyarakat.

Dalam upaya menanggulangi kasus perjudian misalnya, pemerintah mengira, bahwa dengan perubahan sanksi pidana yang ringan menjadi sangat berat bagi bandar dan penjudi, lalu perjudian menjadi lebih tertib. ${ }^{31}$ Tapi kenyataannya, perjudian tetap merajalela sampai sekarang, begitu pula halnya dengan tindak pidana lalu lintas. Dari pengalamanpengalaman itu kemudian muncul suatu keyakinan bahwa penghukuman yang keras tidak mengendalikan kejahatan. Oleh karenanya mereka kembali menggunakan asas subsidiaritas. ${ }^{32}$

Latar belakang semakin perlunya menggunakan asas subsidiaritas dalam penentuan perbuatan terlarang didorong oleh dua faktor. Pertama, penggunaan asas subsidiaritas akan mendorong lahirnya hukum pidana yang adil. Kedua, praktek perundang-undangan menimbulkan dampak negatif terhadap sistem hukum pidana akibat adanya "overcriminalisasi" dan "overpenalisasi" sehingga hukum pidana menjadi kehilangan pengaruhnya dalam masyarakat. Di samping itu, overkriminalisasi dan overpenalisasi semakin memperberat beban kerja aparatur hukum dalam proses peradilan pidana. Akibat selanjutnya, hukum pidana tidak dapat berfungsi dengan baik dan karenanya pula kehilangan wibawa. ${ }^{33}$

Ketiga, selain asas legalitas dan asas subsidiaritas, ada asas lain yang juga mempunyai kedudukan penting dalam proses kriminalisasi, yaitu asas persamaan/kesamaan. Kesamaan adalah kesederhanaan dan kejelasan. Kesederhanaan serta kejelasan itu akan menimbulkan ketertiban.

\footnotetext{
${ }^{30}$ Ibid., hlm. 58.

${ }^{31}$ Aruan Sakidjo dan Bambang Poernomo, Hukum Pidana, Jakarta: Ghalia Indonesia, 1990, hlm. 45.

${ }^{32}$ Ibid., hlm. 50.

${ }^{33}$ Roeslan Saleh, Op. Cit., Asas Hukum , hlm. 48.
} 
Menurut Servan dan Letrossne asas kesamaan bukanlah pernyataan dari aspirasi tentang hukum pidana yang lebih adil. Asas kesamaan lebih merupakan suatu keinginan diadakannya sistem hukum pidana yang lebih jelas dan sederhana. ${ }^{34}$ Sedangkan Lacretelle berpendapat bahwa asas kesamaan tidaklah hanya suatu dorongan bagi hukum pidana yang bersifat adil, tetapi juga untuk hukuman pidana yang tepat. ${ }^{35}$

Asas-asas kriminalisasi tersebut ini adalah asas-asas yang bersifat kritis normatif. Dikatakan kritis, oleh karena dia dikemukakan sebagai ukuran untuk menilai tentang sifat adilnya hukum pidana, dan normatif oleh karena dia mempunyai fungsi mengatur terhadap kebijaksanaan pemerintah dalam bidang hukum pidana. ${ }^{36}$

\section{Kriteria Kriminalisasi}

Dalam membahas masalah kriminalisasi timbul dua pertanyaan, yaitu: (i) apakah kriteria yang digunakan oleh pembentuk undang-undang dalam mengkriminalisasi suatu perbuatan sebagai tindak pidana yang diancam dengan sanksi pidana tertentu?, (ii) Apakah kriteria yang digunakan pembentuk undang-undang untuk menetapkan ancaman pidana terhadap tindak pidana yang satu lebih tinggi daripada ancaman pidana terhadap tindak pidana yang lain. ${ }^{37}$

Dalam menentukan perilaku apa yang akan dikriminalisasi seharusnya diawali dengan pertanyaan: apakah suatu perilaku selayaknya dapat diserahkan kepada private ethics ataukah ia telah menjadi bagian dari ranah (domain) publik? ${ }^{38}$ Perilaku-perilaku yang masuk wilayah privat tidak perlu dikriminalisasi, sedangkan perilaku yang masuk wilayah dapat dikriminalisasi jika sangat merugikan kepentingan masyarakat.

Menurut Bassiouni, keputusan untuk melakukan kriminalisasi dan dekriminalisasi harus didasarkan pada faktor-faktor kebijakan tertentu yang mempertimbangkan bermacam-macam faktor termasuk: ${ }^{39}$

${ }^{34}$ Ibid., hlm. 36-37.

${ }^{35}$ Ibid., hlm. 38-39.

${ }^{36}$ Ibid., hlm. 14.

${ }^{37}$ Rusli Effendi, dkk, Op.Cit., hlm. 34-35.

${ }^{38}$ Harkristuti Harkrisnowo mengutip Bentham dalam "Konsep Pemidanaan: Suatu Gugatan Terhadap Proses Legislasi di Indonesia", Pidato Pengukuhan Guru Besar, UI, Jakarta, hlm. 20.

${ }^{39}$ M. Cherif Bassiouni, “Substantive Criminal Law", 1978, hlm. 82. Dikutip dari Barda Nawawi Arief, Bunga Rampai Kebijakan Hukum Pidana, Bandung: Citra Aditya Bhakti, 1996 
a. Keseimbangan sarana yang digunakan dalam hubungannya dengan hasil-hasil yang ingin dicapai,

b. Analisis biaya terhadap hasil-hasil yang diperoleh dalam hubungannya dengan tujuan-tujuan yang ingin dicari,

c. Penilaian atau penaksiran tujuan-tujuan yang dicari itu dalam kaitannya dengan prioritas-prioritas lainnya dalam pengalokasian sumber-sumber tenaga manusia, dan

d. Pengaruh sosial kriminalisasi dan dekriminalisasi yang berkenaan dengan atau dipandang dari pengaruh-pengaruhnya yang sekunder.

Pandangan lain dikemukakan oleh Soedarto yang mengungkapkan bahwa dalam menghadapi masalah kriminalisasi, harus diperhatikan halhal sebagai berikut: ${ }^{40}$

a. Penggunaan hukum pidana harus memperhatikan tujuan pembangunan nasional, yaitu mewujudkan masyarakat adil dan makmur yang merata materiil dan spiritual berdasarkan Pancasila. Sehubungan dengan ini, (penggunaan) hukum pidana bertujuan untuk menanggulangi kejahatan dan mengadakan pengugeran terhadap tindakan penanggulangan itu sendiri demi kesejahteraan dan pengayoman masyarakat.

b. Perbuatan yang diusahakan untuk dicegah atau ditanggulangi dengan hukum pidana harus merupakan perbuatan yang tidak dikehendaki, yaitu perbuatan yang mendatangkan kerugian (materiil atau spiritual) atas warga masyarakat.

c. Penggunaan hukum pidana harus pula memperhitungkan prinsip biaya dan hasil (cost benefit principle).

d. Penggunaan hukum pidana harus pula memperhatikan kapasitas atau kemampuan daya kerja dari badan-badan penegak hukum, yaitu jangan sampai ada kelampauan beban tugas (overbelasting).

Kriteria kriminalisasi yang dikemukakan Soedarto di atas mempunyai persamaan dengan kriteria kriminalisasi hasil rumusan (kesimpulan) Simposium Pembaruan Hukum Pidana (1976) yang menyebutkan beberapa kriteria umum sebagai berikut ${ }^{41}$

a. Apakah perbuatan itu tidak disukai atau dibenci oleh masyarakat karena merugikan, atau dapat merugikan, mendatangkan korban atau dapat mendatangkan korban?

b. Apakah biaya mengkriminalisasi seimbang dengan hasilnya yang akan dicapai, artinya cost pembuatan undang-undang, pengawasan dan penegakan hukum, serta beban yang dipikul oleh korban, dan pelaku

\footnotetext{
${ }^{40}$ Sudarto, Op.Cit., hlm. 44-48.

${ }^{41}$ Barda Nawawi Arief, Op.Cit., hlm. 38-40.
} 
kejahatan itu sendiri harus seimbang dengan situasi tertib hukum yang akan dicapai?

c. Apakah akan makin menambah beban aparat penegak hukum yang tidak seimbang atau nyata-nyata tidak dapat diemban oleh kemampuan yang dimilikinya?

d. Apakah perbuatan-perbuatan itu menghambat atau menghalangi citacita bangsa Indonesia sehingga merupakan bahaya bagi keseluruhan masyarakat?

Hullsman mengajukan beberapa kriteria absolut yang perlu diperhatikan dalam proses kriminalisasi, yaitu sebagai berikut: ${ }^{42}$

a. Kriminalisasi seharusnya tidak ditetapkan semata-mata atas keinginan untuk melaksanakan suatu sikap moral tertentu terhadap suatu bentuk perilaku tertentu.

b. Alasan utama untuk menetapkan satu perbuatan sebagai tindak pidana seharusnya tidak pernah didirikan suatu kerangka untuk perlindungan atau perlakuan terhadap seorang pelaku kejahatan potensial dalam kepentingannya sendiri.

c. Kriminalisasi tidak boleh berakibat melebihi kemampuan perlengkapan peradilan pidana.

d. Kriminalisasi seharusnya tidak boleh dipergunakan sebagai suatu tabir sekedar pemecahan yang nyata terhadap suatu masalah.

Adapun menurut Moeljatno ada tiga kriteria kriminalisasi dalam proses pembaruan hukum pidana. Pertama, penetapan suatu perbuatan sebagai perbuatan terlarang (perbuatan pidana) harus sesuai dengan perasaan hukum yang hidup dalam masyarakat. Kedua, apakah ancaman pidana dan penjatuhan pidana itu adalah jalan yang utama untuk mencegah dilanggarnya larangan-larangan tersebut. Ketiga, apakah pemerintah dengan melewati alat-alat negara yang bersangkutan, betulbetul mampu untuk benar-benar melaksanakan ancaman pidana kalau ternyata ada yang melanggar larangan. ${ }^{43}$

Menurut Peter W. Low, dalam melakukan kriminalisasi perlu mengukur efek-efek yang mungkin timbul dari pelaksanaan kriminalisasi. Ada tiga (3) efek yang perlu diukur, yaitu, pertama, manfaat kriminalisasi terhadap masyarakat. Pertanyaannya adalah, apakah kriminalisasi lebih banyak membawa manfaat atau tidak kepada masyarakat. Tidak mudah mengukur manfaat kriminalisasi karena adanya kesulitan membedakan

${ }^{42}$ Hullsman sebagaimana dikutip Roeslan Saleh dalam, Dari Lembaran Kepustakaan Hukum Pidana, Penerbit Sinar Grafika, Jakarta, 1988, hlm.. 87.

${ }^{43}$ Moeljatno, Azas-Azas Hukum Pidana, Jakarta: PT Bina Cipta, 1985, hlm. 5. 
efek pencegahan bertahap dalam skema kriminalisasi tertentu dari efekefek yang bisa dicapai dengan metode non-pidana melalui peraturan hukum maupun sarana-sarana kontrol sosial lain. Di samping itu, adanya kesulitan menghitung dampak perilaku tertentu dalam kriminalisasi. Tidak mudah mengukur manfaat kriminalsasi juga berkaitan dengan adanya fakta bahwa 'kriminalisasi' adalah sebuah variabel yang dengan sendirinya bisa dimanipulasi karena efek keperilakuan akan tergantung pada definisi perilaku yang dilarang.

Kedua, mengukur biaya kriminalisasi yang meliputi aspek pencegahan perilaku yang bernilai sosial, pengeluaran untuk penegakan, efek pada individu, efek pada privasi, efek kriminogenik, dan tarif kejahatan. Pencegahan perilaku yang bernilai sosial melalui pelarangan pidana dapat mencegah perilaku yang sah menurut hukum agar tidak masuk ke perilaku yang dilarang hukum. Besarnya efek ini bervariasi karena tidak menentunya pelarangan dan sifat instrumental perilaku yang dilarang

Pengeluaran biaya untuk penegakan hukum berkaitan dengan anggaran untuk berbagai sumberdaya yang digunakan untuk mendeteksi dan menghukum pelanggar. Pada sejumlah kasus, sumberdaya yang digunakan untuk penegakan hukum bagi pelanggaran tertentu paling tepat dipandang sebagai 'biaya kesempatan', yaitu sumberdaya yang mestinya telah atau dapat digunakan untuk menegakkan hukum pidana lain.

Selain aspek pencegahan perilaku yang bernilai sosial dan pengeluaran untuk penegakan, biaya kriminalisasi yang lain adalah efek kriminalisasi pada individu. Tidak semua 'kepedihan' hukuman bisa diukur dengan skala ekonomi, atau bahkan dengan skala psikologis. Namun, kita bisa mendeskripsikan efek penahanan, penuntutan, pendakwaan, dan penghukuman pada pelanggar-pelanggar individual. Ini meliputi pengurangan produktivitas yang disebabkan oleh stigmatisasi (pemberian cap buruk) dan pengungkungan, dampak buruk bagi keluarga yang di tanggung, dan kerugian psikis dan fisik yang bisa terjadi sebagai akibat pemenjaraan.

Komponen biaya yang lain adalah efek yang ditimbulkan kriminalisasi pada privasi seseorang. Stephen dan Devlin mengakui bahayanya mengkriminalisasi perilaku yang terjadi dalam ranah privat yang tidak menimbulkan kerugian bagi orang lain. Permasalahannya adalah bahwa penegakan hukum ini mengharuskan polisi menggunakan teknik-teknik investigasi yang "intrusive" yang melanggar privasi. 
Selanjutnya efek kriminogenik yang timbul akibat kriminalisasi. Sejumlah pelarangan memiliki konsekuensi kriminogenik, yaitu, menciptakan keadaan-keadaan yang meningkatkan kemungkinan timbulnya aktivitas kejahatan yang tidak akan terjadi seandainya tidak ada pelarangan dalam hal tertentu. Menurut para teoritisi pelabelan, respon resmi terhadap suatu penyimpangan, terutama melalui proses stigmatisasi dalam hukum pidana, meningkatkan kemungkinan penyimpangan lebih lanjut oleh individuindividu lain yang belum melakukannya.

Ada pula biaya yang harus diukur akibat penegakan hukum yang setengah hati. Tingkat penegakan yang sesungguhnya ditentukan berdasar alokasi sumberdaya penyelidikan dan penuntutan serta prevalensi (maraknya) perilaku yang dilarang.

Di samping itu, komponen biaya lain yang harus diukur adalah tarif kejahatan. Pelarangan terhadap aktivitas komersial seperti perjudian, seks, pornografi, dan obat-obatan terlarang jelas mengurangi pasokan barang dan jasa yang dilarang, tapi sepanjang ada pembelinya, maka muncul pasar komersial gelap. Seberapa besar pelarangan bisa mengurangi aktivitas yang tidak dikehendaki sangat tergantung pada elastisitas permintaan, yaitu respon calon konsumen terhadap peningkatan harga.

Tarif kejahatan mempunyai tiga konsekuensi sosial. Pertama, pendapatan yang sangat besar yang dihasilkan oleh illegal trafficking atas barang-barang yang dilarang tidak terkena pajak. Kedua, para pengusaha pasar gelap memiliki dorongan yang kuat, dan modal yang kuat untuk mengambil langkah apa pun yang diperlukan untuk melindungi investasi mereka dan mengurangi risiko penghukuman. Korupsi oleh para penegak hukum juga akan merajalela. Selain itu, tarif kejahatan yang tinggi untuk perdagangan obat, seks, dan perjudian membentuk kondisi ekonomi yang memungkinkan organisasi kejahatan skala-besar tumbuh subur. Akhirnya, kualitas barang dan jasa haram beragam, masyarakat mendapatkan manfaat dari regulasi: pelacur tidak perlu diperiksa dan dirawat atas penyakit-penyakit kelamin yang dideritanya; pendirian tempat judi tidak dimonitor kemungkinan terjadinya praktik kecurangan; dan obat tidak diuji kemurniannya. ${ }^{44}$

Selain mengukur manfaat dan biaya, pelaksanaan kriminalisasi harus menimbang untung dan rugi. Menurut Junker, argumen untung-rugi

${ }^{44}$ Peter W. Low, dkk., Criminal Law: Cases and Materials, New York: The Foundation Press,. Inc., 1986, hlm.1075-1080. 
dalam dekriminalisasi adalah paham libertarianisme terselubung, dan bahwa para pendukungnya secara implisit merongrong legitimasi dan manfaat pelarangan itu bagi masyarakat. ${ }^{45}$

\section{Penutup}

Ada beberapa kesimpulan yang dapat ditarik dari uraian tersebut. Pertama, kriminalisasi terbatas pada penetapan suatu perbuatan sebagai tindak pidana yang diancam dengan sanksi pidana. Pengertian kriminalisasi tidak terbatas pada penetapan suatu perbuatan sebagai tindak pidana dan dapat dipidana, tetapi juga penambahan (peningkatan) sanksi pidana terhadap tindak pidana yang sudah ada. Kedua, kriminalisasi merupakan masalah yang kompleks karena adanya perbedaan jenis perbuatan yang dapat dikriminalisasi, perbedaan nilai dan norma dalam masyarakat, beragamnya pilihan instrumen pengaturan kehidupan masyarakat, dan perubahan sosial yang terjadi dalam masyarakat.

Ketiga, asas penting yang perlu diperhatikan dalam kriminalisasi adalah asas legalitas, asas subsidiaritas, dan asas persamaan di muka hukum. Akhirnya, kriteria yang perlu dipertimbangkan dalam kriminalisasi meliputi: perbuatan yang dikriminalisasi adalah perbuatan yang tidak dikehendaki menurut rasa keadilan masyarakat, kemampuan hukum pidana mengatasi masalah yang dikriminalisasi, keseimbangan antara sarana dan hasil atau manfaat yang diperoleh melalui kriminalisasi, keseimbangan antara biaya dan hasil, dampak negatif dari kriminalisasi, dan kemampuan badan peradilan dan aparatur penegak hukum menegakkan perbuatan yang dikriminalisasi.

\footnotetext{
${ }^{45}$ Ibid., dikutip dari Junker, "Criminalization and Criminogenesis", at 19 UCLA
} L. Rev. 697 (1972). 


\section{Daftar Pustaka}

Abdullah Ahmed An-Naim, Dekonstruksi Syari'ah, Yogyakarta, LkiS dan Pustaka Pelajar, 1990

A.P. Simester dan G R Sullivan, Criminal Law Theory and Doctrine, Oxford: Hart Publishing, 2000.

Aruan Sakidjo dan Bambang Poernomo, Hukum Pidana, Jakarta: Ghalia Indonesia, 1990.

Barda Nawawi Arief, Bunga Rampai Kebijakan Hukum Pidana, Bandung: Citra Aditya Bhakti, 1996.

Harkristuti Harkrisnowo “Konsep Pemidanaan: Suatu Gugatan Terhadap Proses Legislasi di Indonesia", Pidato Pengukuhan Guru Besar, UI, Jakarta.

Henry Campbell Black, Black Law Dictionary, Fifth Edition, Sint Paul Minn: West Publishing Co., 1979.

Hugh D Barlow, Introduction to Criminology, Third Edition, Boston: Little Brown and Company, 1984.

J.E. Sahetapy (Ed.), Hukum Pidana, Yogyakarta: Penerbit Liberty, 1996.

Kamariah, "Ajaran Sifat Melawan Hukum Material Dalam Hukum Pidana Indonesia", 1994,

Moeljatno, Azas-Azas Hukum Pidana, Jakarta: PT Bina Cipta, 1985.

Oemar Adjie, Hukum Pidana Tidak Tertulis, Cetakan pertama, Jakarta: Tri Grafika, 1992.

Paul Cornill, "Criminality and Deviance in a Changing Whorld", 1970.

Peter W Lowdkk., Criminal Law: Cases and Materials, New York: The Foundation Press., Inc., 1986.

Roeslan Saleh, Asas Hukum Pidana Dalam Perspektif, Jakarta: Aksara Baru, 1981.

, “Kebijakan Kriminalisasi Dan Dekriminalisasi: Apa Yang Dibicarakan Sosiologi Hukum Dalam Pembaruan Hukum Pidana Indonesia", 1993

Soerjono Soekanto, Kriminologi Suatu Pengantar, Cetakan Pertama, Jakarta:Ghalia Indonesia, 1981

Sudarto, Kapita Selekta Hukum Pidana, Bandung: Alumni, 1986. Wignjosoebroto, Soetandyo, "Kriminalisasi Dan Dekriminalisasi: Apa Yang Dibicarakan Sosiologi Hukum Tentang Hal Ini", 1993

BPHN, Simposium Pembaruan Hukum Pidana Nasional Indonesia, 
Jakarta, Binacipta. 1986.

Kesadaran Hukum Masyarakat dalam Masa Transisi, Jakarta: Binacipta, tanpa tahun. 